\title{
THE EFFECTS OF AVIAN GONADOTROPHIN PRECIPITATE ON PITUITARY-DEFICIENT HENS
}

\author{
MARGARET E. MITCHELL* \\ Physiological Laboratory, Cambridge
}

(Received 25th November 1966)

\begin{abstract}
Summary. Hypophysectomized hens and hens treated with a pituitaryinhibiting drug were injected with a partially purified preparation of avian pituitary glands. Ovarian weight and follicle size were measured, and also oviduct weight as an indicator of ovarian endocrine activity. Thyroid stimulation was detected by a histological study. It was demonstrated that the preparation used contained all or most of the gonadotrophin and thyrotrophin activity of the original acetone-dried material.
\end{abstract}

\section{INTRODUCTION}

Gonadotrophin injections have been used to delay ovarian regression in hypophysectomized hens (Nalbandov, 1953) and in birds rendered pituitarydeficient by inanition (Hosoda, Kaneko, Mogi \& Abe, 1955, 1956). Comparisons of a number of gonad-stimulating preparations have suggested that crude avian pituitary material was more successful than purified mammalian hormones for stimulation of the avian ovary, both after hypophysectomy (Opel \& Nalbandov, 1961) and in starving pullets (Morris \& Nalbandov, 1961). In hens treated with the anti-gonadotrophin drug, I.C.I. Compound 33,828, the fully regressed ovary was stimulated with avian pituitary material (Mitchell, 1966), and both endocrine activity and follicle development resulted. Similar ovarian activity was induced in hypophysectomized hens in which postoperative regression of the gonad and gonad-dependent organs had been allowed to develop (Mitchell, 1967). A crude acetone-dried anterior lobe preparation, such as was used for these studies, has been partially purified, and the ovary-stimulating activity of the presumed gonadotrophin precipitate has been tested on hypophysectomized hens and hens treated with the pituitary inhibitor. Thyroid stimulation was detected histologically.

\section{MATERIALS AND METHODS}

Chicken pituitary gonadotrophin (CPG)

Acetone-dried broiler pituitary glands were powdered, yielding $1.2 \mathrm{mg} /$ gland (Wright, 1965). The crude powder was extracted with $6 \%$ ammonium acetate solution in $40 \%$ ethanol, at $\mathrm{pH} 5 \cdot 1$, and, after removal of insoluble material by

* Present address: A.R.C. Poultry Research Centre, Edinburgh 9. 
centrifugation, protein was precipitated from the supernatant by addition of ethanol to produce an $80 \%$ solution. This process was based on a method for human pituitary fractionation (Butt, Crooke \& Cunningham, 1961) and yielded $4.2 \%$ precipitate (by weight) of the initial powder (Hartree, unpublished data), equivalent to $0.045 \mathrm{mg} /$ gland.

\section{Pituitary deficient hens}

The birds used throughout the study were adult Light Sussex hens, weighing 2.0 to $2.5 \mathrm{~kg}$ and in laying condition at the start of the experiments.

Hypophysectomy. Surgical hypophysectomy was performed by a modification of the transbuccal approach of Hill \& Parkes (1934). A post-operative period of 10 to 14 days was allowed for regression of the ovary and oviduct (Mitchell, 1967). Completeness of hypophysectomy was always confirmed by histological examination of the sella turcica.

Pituitary inhibition. The non-steroid inhibitor of pituitary gonadotrophin function, I.C.I. Compound 33,828 (Paget, Walpole \& Richardson, 1961), was administered as $0.02 \%$ of the normal ration. After 4 weeks, all treated hens were laparotomized, and selection was made for birds in which ovarian regression was complete (Mitchell, 1966). A period of 2 days was allowed for recovery from laparotomy, before hormone injections were started. Feeding on the medicated diet continued throughout the experiments.

\section{Experimental procedure}

The gonadotrophin precipitate was dissolved in physiological saline, and injections of $1.0 \mathrm{ml}$ were given daily into the pectoral muscle, for 12 days in hypophysectomized hens and 8 or 16 days in hens treated with the inhibitor. In an experiment with hypophysectomized hens injections were given for 14 days, the last two being accompanied by intravenous $\mathrm{LH}$ injection into the wing vein. All injections were given between 11.00 and 12.00 hours. Autopsy was carried out on the 2nd day following the last injection. Ovary and oviduct weights and follicular diameters were recorded and the thyroid glands were retained for histological study.

\section{Thyroid histology}

The thyroids were fixed in Bouin's fixative, and sections $6 \mu$ thick were stained in haemalum and eosin, or in Heidenhain's azan stain. Measurements of epithelial cell height were taken at random, and an approximate mean value was obtained from ten measurements for each gland.

\section{EXPERIMENTS AND RESULTS}

Hypophysectomized hens

Controls. Data for ovary and oviduct weights of uninjected hypophysectomized hens were available from a control experiment in which regression rates of these organs were determined (Mitchell, 1967). Two hens were killed 10.5 and 12.5 days after pituitary removal, corresponding approximately to the time at which hormone injections started in experimental birds, and another four were 
killed 20 to 28 days after hypophysectomy, equivalent to the total of postoperative period +treatment period for the experiments described below (see Table 1).

Experiment 1. Six hypophysectomized hens were injected daily for 12 days with $2.0 \mathrm{mg}$ of the GPG precipitate. During treatment, the general condition

TABLE 1

OVARY AND OVIDUCT WEIGHTS OF HYPOPHYSEGTOMIZED GONTROLS

\begin{tabular}{c|c|c|c}
\hline $\begin{array}{c}\text { Bird } \\
\text { No. }\end{array}$ & $\begin{array}{c}\text { Period after } \\
\text { hypophy- } \\
\text { sectomy } \\
(\text { days })\end{array}$ & $\begin{array}{c}\text { Ovary } \\
\text { weight } \\
(\mathrm{g})^{*}\end{array}$ & $\begin{array}{c}\text { Oviduct } \\
\text { weight } \\
(\mathrm{g})^{*}\end{array}$ \\
\hline 56 & $10 \cdot 5$ & $1 \cdot 5$ & $8 \cdot 0$ \\
53 & $12 \cdot 5$ & $2 \cdot 2$ & $13 \cdot 2$ \\
18 & 20 & $2 \cdot 2$ & $8 \cdot 0$ \\
27 & 20 & $1 \cdot 5$ & $7 \cdot 0$ \\
30 & 27 & $1 \cdot 2$ & $4 \cdot 5$ \\
33 & 28 & $1 \cdot 3$ & $4 \cdot 0$ \\
\hline
\end{tabular}

of three deteriorated rapidly. Food intake ceased and the hens lost weight and became comatose. All six were given an intramuscular injection of $2.5 \mathrm{mg}$ prednisolone trimethylacetate (Ultracortenol, Ciba Laboratories Ltd) in crystalline suspension on Day 8 of the injection period, and this was repeated on Day 11 for the three hens in poor condition. A protein and glucose solution was

TABLE 2

TREATMENT OF HYPOPHYSEGTOMIZED HENS WITH $2.0 \mathrm{mg}$ AVIAN GONADOTROPHIN PRECIPITATE DAILY-EXP. 1

\begin{tabular}{|c|c|c|c|c|c|c|c|c|}
\hline \multirow{2}{*}{$\begin{array}{l}\text { Bird } \\
\text { No. }\end{array}$} & \multirow{2}{*}{$\begin{array}{c}\text { Ovary } \\
\text { weight } \\
(\mathrm{g})\end{array}$} & \multirow{2}{*}{$\begin{array}{l}\text { Oviduct } \\
\text { weight } \\
(g)\end{array}$} & \multicolumn{5}{|c|}{ Normal follicles ( $\mathrm{cm}$ diameter) } & \multirow{2}{*}{$\begin{array}{l}\text { Atrophic } \\
\text { follicles }\end{array}$} \\
\hline & & & 0.5 to 0.9 & 1.0 to 1.4 & 1.5 to 1.9 & $2 \cdot 0$ to $2 \cdot 4$ & $2 \cdot 5$ to 2.9 & \\
\hline $\begin{array}{l}95^{*} \dagger \\
96 * \\
98\end{array}$ & $\begin{array}{l}68 \cdot 0 \\
68 \cdot 4 \\
48 \cdot 0\end{array}$ & $\begin{array}{l}50 \cdot 4 \\
42 \cdot 5 \\
50 \cdot 0\end{array}$ & $\begin{array}{l}30 \\
30 \\
-\end{array}$ & $\begin{array}{r}10 \\
50 \\
1\end{array}$ & $\begin{array}{l}- \\
\overline{2}\end{array}$ & $\overline{\overline{2}}$ & $\begin{array}{l}- \\
\overline{1}\end{array}$ & 3 oldest \\
\hline $\begin{array}{l}100^{*} \\
101 \\
102\end{array}$ & $\begin{array}{l}16 \cdot 0 \\
32 \cdot 0 \\
21 \cdot 0\end{array}$ & $\begin{array}{l}50 \cdot 0 \\
54 \cdot 0 \\
46 \cdot 0\end{array}$ & $\begin{array}{l}20 \\
-\overline{30}\end{array}$ & $\begin{array}{l}- \\
- \\
-\end{array}$ & $\overline{8}$ & $\overline{1}$ & - & $\begin{array}{l}- \\
- \\
-\end{array}$ \\
\hline $\begin{array}{l}\text { Mean } \\
\pm \text { S.E. }\end{array}$ & $\begin{array}{r}42 \cdot 2 \\
\pm 10.0\end{array}$ & $\begin{array}{r}48.8 \\
\pm 1.2\end{array}$ & & & & & & \\
\hline
\end{tabular}

* Hens in poor condition.

$\uparrow$ Died on Day $14=$ day of autopsy.

administered by crop tube daily to offset the lack of voluntary feeding. These measures effected some improvement in two hens, but the third died on the day scheduled for autopsy.

Post-mortem examination on Day 14 revealed that all six had responded to some extent to the treatment. In one ovary (No. 98) a graded series of follicles 
had developed, the three oldest of which were atrophic. In the others, there was some degree of over-stimulation of the smaller sizes (see Table 2). All oviducts had developed to a size very similar to that of a normal laying hen. It was observed that, by the end of the experiment, comb size had increased greatly in all these hens.

Experiment 2. In a second experiment with six hens receiving the same daily dose of CPG, the Ultracortenol injections were given every 3rd day, starting on Day 1 of the injection period. By Day 12, comb size in all six resembled that of a laying hen, and all birds were in good condition. Plate 1, Fig. 1 shows the head furnishings of one of these, compared with those of an untreated control hypophysectomized on the same day and given cortisone injections at the same times as the treated bird. The degree of comb development suggested that considerable ovarian stimulation had taken place, and the injection period was, therefore, extended for a further 2 days, when 50 i.u. of HCG were injected to the wing vein at the same time as the intramuscular injections of CPG.

TABLE 3

EFFEGTS ON OVARY AND OVIDUCT OF HYPOPHYSEGTOMIZED HENS FOLLOWING DAILY TREATMENT WITH $2.0 \mathrm{mg}$ AVIAN GONADOTROPHINS-EXP. 2

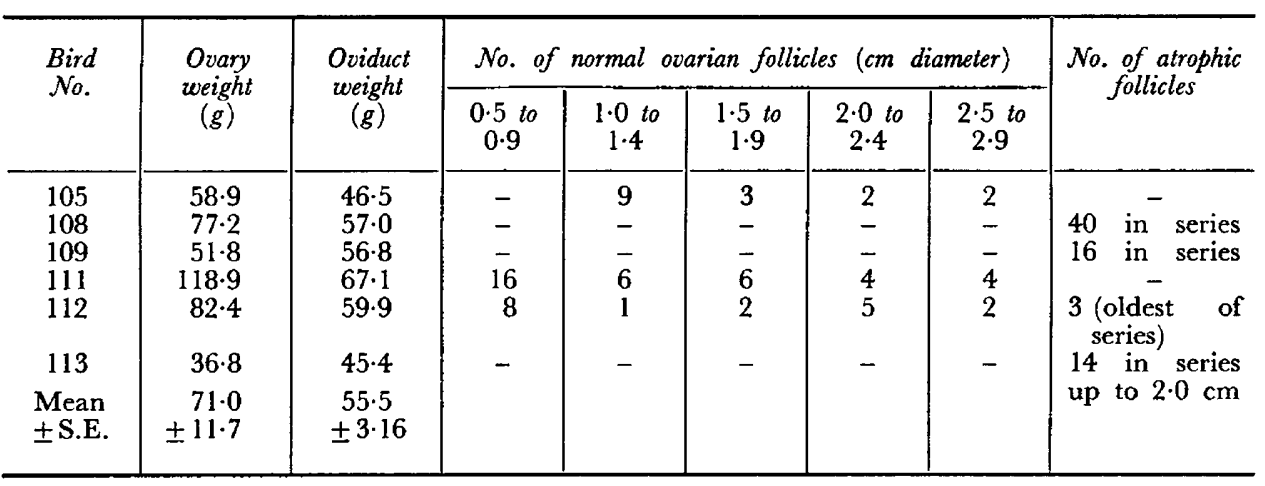

At autopsy on Day 16, it was confirmed that all had responded to treatment by massive follicular development, accompanied by oviduct growth, as in Exp. 1. The complete series was atrophic in three of the six and in the others normal follicles remained, showing some overstimulation of the small size classes (see Table 3). No ruptured follicles were found, indicating that the intravenous injections had not induced ovulation. In none of the six ovaries was a normal follicle found greater than $3.0 \mathrm{~cm}$ diameter, at which size ovulation would occur in an intact hen.

\section{Pituitary-deficient hens}

Controls. Preliminary experiments with hens treated with I.C.I. Compound 33,828 established that ovary and oviduct weights varied greatly (Mitchell, 1966). Although inhibition of egg production was completely successful at the dietary level of $0.02 \%$, the degree of ovarian regression was unpredictable from observation of external characters. Hens were, therefore, laparotomized after 


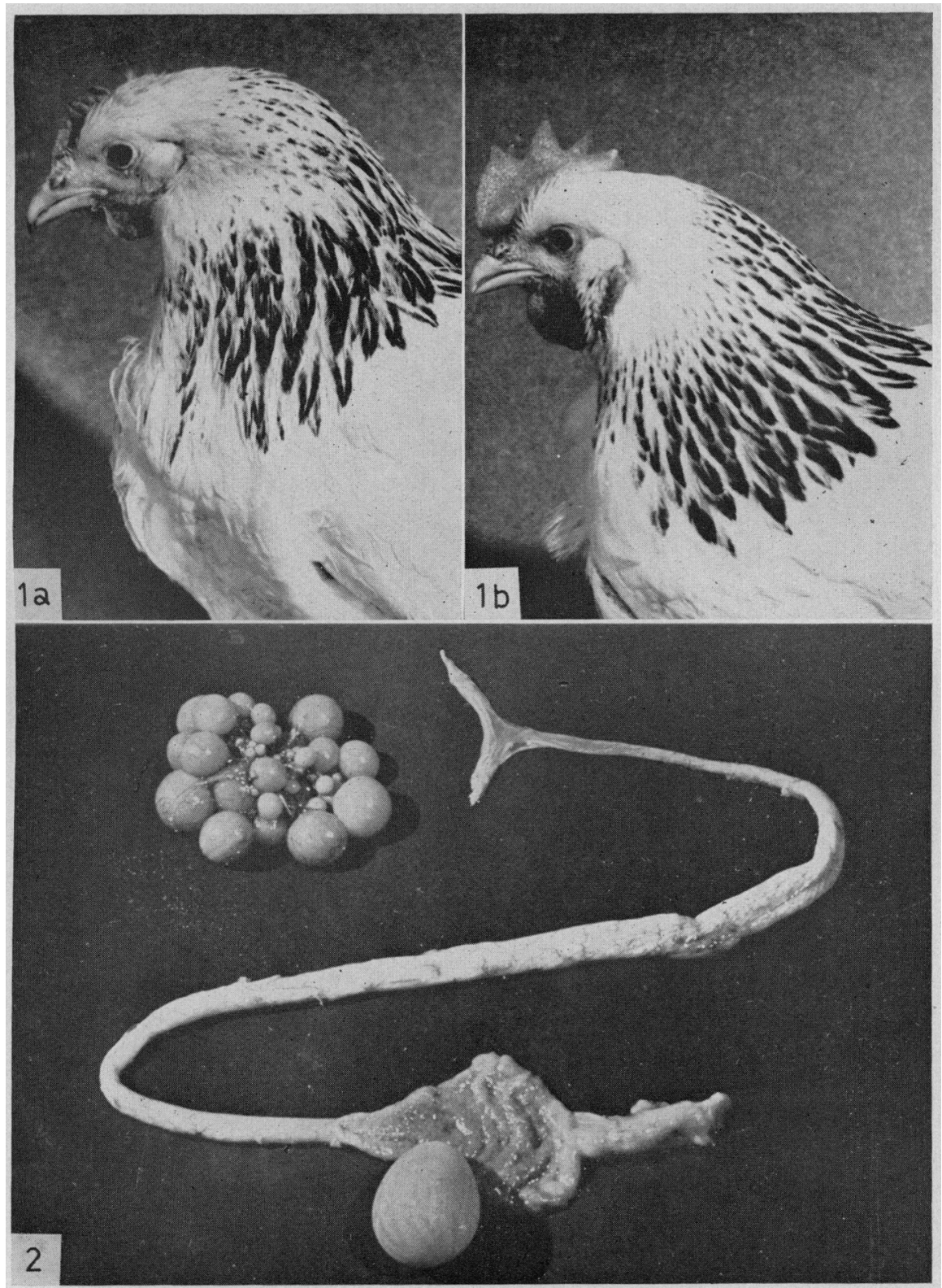

lirf. 1. Head fumishings of I ight Sussex hens. 21 days after hypophysectomy. (a) Lntreated control, (b) trealed with $2.0 \mathrm{mg}$ avian gonadotrophin precipitate daily, from 10 dats after pituitary remosal. Note marked increase in size and turgidity of comb and wattes.

Fix. 2. ONary and widuct of a hen with the inhibitory effect of IC: Compound 33.828

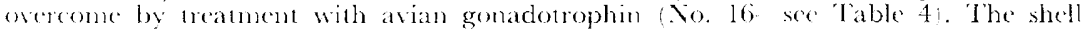
gland is shown dissected open, with the soft-shelled egg removed. 
PLATE 2

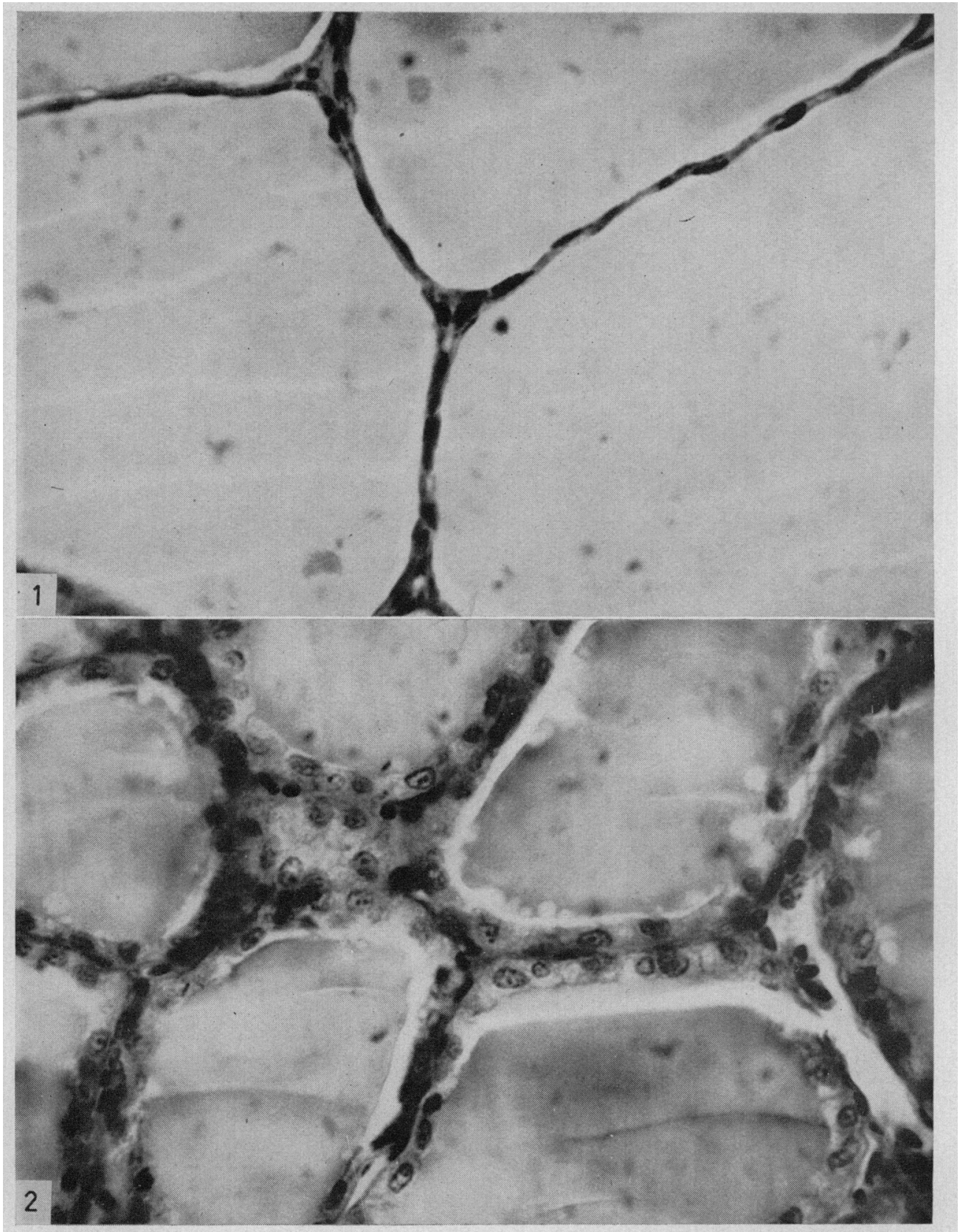

Thyroid histology. Thickness of sections, $6 \mu$; stain, Heidenhain's azan triple stain, $\times 1000$.

FIG. 1. Section of thyroid gland from hypophysectomized hen 27 days afte pituitary removal. Epithelial cells are flattened to a height of 1 to $1.5 \mu$ with nuclei small and densely stained.

Fig. 2. Thyroid section from $\mathrm{Hx} 98$ (injected for 12 days with $1.0 \mathrm{mg}$ cPG daily). Cell height is approximately $3 \mu$ and the nuclei are large, with darkly stained granules. 
a period of 3 to 4 weeks on the medicated diet, and only included in experiments if found to have a greatly regressed ovary. A sample of six such hens was killed after laparotomy, and organ weights were recorded. Mean ovary weight was $5.5 \mathrm{~g}$, and mean oviduct weight, $12.9 \mathrm{~g}$.

Experiment 3. Six hens were laparotomized, two of which were found to be suitable for treatment. They were injected daily for 8 days with $1.5 \mathrm{mg}$ GPG precipitate and killed on the 10th day. Both ovaries were greatly over-stimulated, with excess of follicles of all sizes (see Table 4). In one, atresia had just begun and had affected one large and two small follicles. The other hen had ovulated, probably on Day 9. A recently ruptured follicle was detected in the ovary, and an apparently normal egg was found in the shell gland with a small amount of calcareous deposit already formed (see Pl. 1, Fig. 2).

Experiment 4. From a second group of six laparotomized hens, three were

TABLE 4

TREATMENT OF PITUITARY-INHIBITED HENS WITH $1.5 \mathrm{mg}$ AVIAN GONADOTROPHIN PRECIPITATE DAILY-EXP. 3 AND 4

\begin{tabular}{|c|c|c|c|c|c|c|c|c|c|c|c|}
\hline \multirow{3}{*}{$\begin{array}{l}\text { Bird } \\
\text { No. }\end{array}$} & \multirow{3}{*}{$\begin{array}{l}\text { Treat- } \\
\text { ment } \\
\text { period } \\
\text { (days) }\end{array}$} & \multirow{3}{*}{$\begin{array}{c}\text { Ovary } \\
\text { weight } \\
(\mathrm{g})\end{array}$} & \multirow{3}{*}{$\begin{array}{c}\text { Oviduct } \\
\text { weight } \\
\text { (g) }\end{array}$} & \multicolumn{8}{|c|}{ Follicles in ovary } \\
\hline & & & & \multicolumn{6}{|c|}{ Normal (cm diameter) } & \multirow{2}{*}{$\begin{array}{l}\text { Atro- } \\
\text { phic }\end{array}$} & \multirow{2}{*}{$\begin{array}{l}\text { Rup- } \\
\text { tured }\end{array}$} \\
\hline & & & & $\begin{array}{c}0.5 \text { to } \\
0.9\end{array}$ & $\begin{array}{c}1.0 \text { to } \\
1.4\end{array}$ & $\begin{array}{c}2.0 \text { to } \\
1.9\end{array}$ & $\begin{array}{c}2.5 \text { to } \\
2.4\end{array}$ & $\begin{array}{c}2.5 \text { to } \\
2.9\end{array}$ & $\begin{array}{c}3.0 \text { to } \\
3.4\end{array}$ & & \\
\hline LS.1 & 8 & $132 \cdot 0$ & $88 \cdot 4$ & - & 17 & 7 & 5 & 5 & - & 1 large & - \\
\hline LS.16 & 8 & $119 \cdot 2$ & $91 \cdot 0$ & 12 & 6 & 7 & 4 & 5 & 1 & 2 old & 1 \\
\hline $\begin{array}{l}\text { LS. } 2 \\
\text { LS. } 3 \\
\text { LS.4 }\end{array}$ & $\begin{array}{l}16 \\
16 \\
16\end{array}$ & $\begin{array}{l}174 \cdot 8 \\
110.5 \\
135.6\end{array}$ & $\begin{array}{l}59 \cdot 0 \\
65 \cdot 5 \\
85 \cdot 2\end{array}$ & $\begin{array}{l}2 \\
9 \\
-\end{array}$ & $\begin{array}{l}5 \\
4 \\
2\end{array}$ & $\begin{array}{l}5 \\
7 \\
4\end{array}$ & $\begin{array}{l}6 \\
7 \\
4\end{array}$ & $\begin{array}{l}8 \\
2 \\
4\end{array}$ & $\begin{array}{l}3 \\
- \\
-\end{array}$ & $\begin{array}{l}15 \text { small } \\
6 \text { old } \\
8 \text { small }\end{array}$ & $\begin{array}{l}\overline{1} \\
4\end{array}$ \\
\hline
\end{tabular}

LS. 16 soft-shelled egg in shell gland.

LS. 2 laid: Day 5 (soft shell) Day 11 (one normal, one soft shell).

LS. 3 laid: Day 14 (soft shell).

LS. 4 Unabsorbed yolk in body cavity.

selected for an extension to 16 days of the treatment used in Exp. 3. Two of these laid during the course of treatment. LS2 laid a soft-shelled egg on Day 5, a small amount of albumen surrounded by shell membranes but without a central yolk on Day 6 and two small eggs on Day 11; of these, one was normal and one soft-shelled. LS.3 laid a soft-shelled egg on Day 14. At autopsy, all three ovaries were found to be greatly overstimulated, with atresia affecting some small follicles in two (see Table 4). Two recently ruptured follicles were found in the ovary of LS.2, and one in LS.3, presumably corresponding to the eggs laid on Days 11 and 14 respectively. LS.4, which did not lay, had four recently ruptured follicles in the ovary and traces of unabsorbed yolk in the body cavity.

In both Exp. 3 and 4, great oviduct growth accompanied ovary development, together with some comb growth. The latter was less marked than in hypophysectomized hens, as the comb regresses to a lesser extent during pituitary inhibition than after total removal of the anterior lobe. 
Thyroid histology. Epithelial cell heights were measured in sections of thyroid glands of three hypophysectomized controls $(27,30,33$, Table 1$)$. The values ranged from 1.0 to $1.5 \mu$ in two of these, and from 1.5 to $2.0 \mu$ in the third.

Measurements from sections of one gland of four birds from each of Exp. 1 and 2 all ranged from 2.5 to $3.5 \mu$.

Plate 2 shows part of a photomicrograph from a section from one of the hens in Exp. 1 (No. 98, Table 2) compared with a control.

Thyroids from birds on Exp. 3 and 4 were not examined as no difference was detected between uninjected controls fed on the medicated diet and hens fed on normal layers' mash.

\section{DISCUSSION}

By comparison with fractionation of mammalian pituitary material, the precipitate used for these experiments was expected to contain follicle stimulating and luteinizing hormones and thyrotrophin (Butt et al., 1961; Kirkham, 1962). The ovary and oviduct development observed here confirmed that the material had gonad-stimulating properties. The dose levels and treatment periods were selected with reference to the recovery of $4.2 \%$ during precipitation (Hartree, unpublished data) and earlier experiments with the crude acetone-dried pituitary preparation, from which the precipitate was obtained. Hence $2.0 \mathrm{mg}$ precipitate for 12 days was approximately equivalent to treatment with $50 \mathrm{mg}$ crude material for that period, which slightly overstimulated the ovaries of hypophysectomized hens (Mitchell, 1967). A similar effect was produced with $40 \mathrm{mg}$ for 8 days in hens fed on I.C.I. Compound 33,828 (Mitchell, 1966) suggesting the dose of $1.5 \mathrm{mg}$ used here. The similarity of degree of stimulation obtained suggested that all or most of the gonadotrophin had been concentrated in the precipitate.

The marked deterioration of condition in the birds in Exp. 1 was apparently prevented in Exp. 2 by more frequent Ultracortenol injections. This treatment had previously been used successfully to improve post-operative survival of hypophysectomized hens (Mitchell, 1967). It was not required during experiments with crude avian pituitary powder, which would be expected to contain some adrenocorticotrophic hormone, possibly absent in the CPG precipitate.

I.C.I. compound 33,828 has no inhibitory effect on adrenocorticotrophin or thyrotrophin activity (Paget $e t$ al., 1961). Signs of adrenal insufficiency were not observed in hens treated with this substance, nor were differences detected in thyroid histology. Examination of thyroid sections after crude pituitary powder injections (Wright, 1965) showed increased cell heights in hypophysectomized birds, but no difference in hens treated with the inhibitor. The thyroid cell measurements reported here were comparable with those after crude preparation treatment, and suggested that most of the TSH was present in the precipitate.

The observed differences in requirement for dose level and treatment duration in the two groups of pituitary-deficient hens suggested that gonadotrophin activity in the drug-treated birds was not entirely suppressed at the level of medication used. This was also indicated by the ovulations recorded in Exp. 3 and 4, in which no intravenous injections were given to induce ovulation. 
The injections of HCG in Exp. 2 failed to induce ovulation; and may have caused the onset of atresia observed in four of the group. The possible explanations for this failure include unsuitability of nature, dose or timing of the intravenous injections, or absence of ovulable follicles.

A feature of all the ovaries, in which follicles developed, was over-stimulation of the smaller size classes. This may have been caused by excess gonadotrophin, but, in experiments with crude powder, lower doses often failed to induce any follicle growth in some birds (Wright, 1965). Alternatively, the relative proportions of the various pituitary secretions may be critical for normal development of a follicular heirarchy, and such proportions may be lacking in broiler pituitary powder and in the gonadotrophin precipitate prepared from this.

\section{ACKNOWLEDGMENTS}

These experiments form part of the material for a Ph.D. dissertation to the University of Cambridge. They were performed during tenure of a British Egg Marketing Board Studentship, under the helpful supervision of Professor A. S. Parkes. Working expenses were defrayed by a Ford Foundation grant to Professor Parkes.

Thanks are due to Imperial Chemical Industries (Pharmaceutical division) Ltd, for supplies of Compound 33,828, and to Dr A. H. Sykes, Wye College, for help with compounding the medicated diet. The fractionation of pituitary material was performed by Dr A. S. Hartree, Department of Biochemistry, Cambridge, whose help and advice is most gratefully acknowledged.

\section{REFERENCES}

Butt, W. R., Crooke, A. G. \& Cunningham, F. J. (1961) Studies on human urinary and pituitary gonadotrophins. Biochem. 7. 81, 596.

Hill, R. T. \& Parkes, A. S. (1934) Hypophysectomy of birds. I. Technique with a note on results. Proc. R. Soc. B, 115, 402.

Hosoda, K., Kaneko, T., Mogr, K. \& ABe, T. (1955) Effect of gonadotrophic hormone on ovarian follicles and serum vitellin in fasting hens. Proc. Soc. exp. Biol. Med. 88, 502.

Hosoda, K., Kaneko, T., Mogi, K. \& AbE, T. (1956) Forced ovulation in gonadotrophin treated fasting hens. Proc. Soc. exp. Biol. Med. 92, 360.

KIRKham, K. E. (1962) A new bioassay technique for the measurement in vitro of thyrotrophic hormone in serum and in pituitary extracts. F. Endocr. 25, 259.

Miтchell, M. E. (1966) Effect of fowl gonadotrophin following treatment with a pituitary inhibitor. In: Physiology of the Domestic Fowl. Eds. W. Horton Smith and E. C. Amoroso. Oliver \& Boyd, Edinburgh.

MrTChell, M. E. (1967) Stimulation of the ovary in hypophysectomized hens by an avian pituitary preparation. 7. Reprod. Fert. 14, 249.

Morris, T. R. \& Nalbandov, A. V. (1961) The induction of ovulation in starving pullets using mammalian and avian gonadotrophins. Endocrinology, 68, 687.

Nalbandov, A. V. (1953) Endocrine control of physiological functions. Poult. Sci. 32, 88.

Opel, H. L. \& Nalbandov, A. V. (1961) Follicular growth and ovulation in hypophysectomised hens. Endocrinology, 69, 1016.

Paget, G. E., Walpole, A. L. \& Righardoon, D. N. (1961) Non-steroid inhibition of the gonadotrophic function of the pituitary. Nature, Lond. 192, 1194.

WRIGHT, M. E.* (1965) Avian hypophysial hormones in pituitary-deficient fowl. Ph.D. thesis, Cambridge University.

\footnotetext{
* Now: Mitchell, M. E.
} 